\title{
Sugarcane silage production treated with additives at different times post burning ${ }^{1}$
}

\author{
Anna Paula de Toledo Piza Roth ${ }^{2}$, Ricardo Andrade Reis ${ }^{2,3}$, Gustavo Rezende Siqueira ${ }^{4}$, \\ Marcella de Toledo Piza Roth², Flávio Dutra de Resende ${ }^{3,4}$, Rafael Rodrigues Monteiro ${ }^{2}$ \\ 1 Projeto financiado pela FAPESP. \\ ${ }^{2}$ Faculdade de Ciências Agrárias e Veterinárias - Unesp - Campus de Jaboticabal, SP. Via de Acesso Prof. Paulo Donato Castellani, \\ Km 5, s/n. CEP: 14.884-900. \\ ${ }^{3}$ Bolsista de produtividade em pesquisa do CNPq. \\ ${ }^{4}$ Apta - Pólo Regional da Alta Mogiana - Colina, SP.
}

ABSTRACT - This trial aimed to evaluate the effects of the time post-burning, and additives on fermentative characteristics, losses and chemical composition on the sugar cane silage. The sugar cane variety IAC 86-2480 was ensiled on the 1, 4, 7, 10 and 14 days after burning. The additives evaluated were: control (Cont.), Lactobacillus buchneri (LB), Calcium oxide micro pulverized (CO), and Lactobacillus buchneri (LB) plus Calcium oxide micro pulverized (LB + CO). The yeast population was determined before ensiled. After 56 days of the fermentation period the silos were opening to take samplings. The experimental design was a completely randomized design, in a factorial scheme (additive and burning time) with seven treatments and four replications. The sugar cane was recontaminated with yeast, the populations increased from 5.04 to $6.48 \mathrm{log} \mathrm{cfu} / \mathrm{g}$ of forage. Dry matter content decreased after fermentation period in average 7.6 units, compared to the sugar cane forage before ensilage. Control and LB silage showed lowest dry matter recovery (DMR), $613 \mathrm{~g} / \mathrm{kg}$ and $631 \mathrm{~g} / \mathrm{kg}$, respectively, compared to the Cal and LB + Cal, $807 \mathrm{~g} / \mathrm{kg}$ and $832 \mathrm{~g} / \mathrm{kg}$. This fact probably was associated to the calcium oxide control on the yeast populations. In relation to the time post-burning, the greatest changes were observed in the gas production and DMR. Gas production were higher in the first days post-burning and decreased in response to the prolongation time post-burning. The time post-burning alters the nutritive value of the fresh sugarcane and its silage and also the size of the losses from the ensilage process.

Key Words: calcium oxide micro pulverized, ensilage, inoculants, Lactobacillus buchneri

\section{Produção de silagens de cana-de-açúcar tratada com aditivos em diferentes tempos após a queima}

RESUMO - Objetivou-se estudar a ação do tempo após a queima do canavial e o uso de aditivos sobre as características fermentativas, as perdas e a composição química de silagens de cana-de-açúcar. A cultivar utilizada foi a IAC 86-2480 colhida em cinco tempos (1, 4, 7, 10 e 14 dias) pós-queima. Os aditivos utilizados foram controle, sem aditivos, Lactobacillus buchneri, cal virgem micropulverizada e Lactobacillus buchneri + cal virgem micropulverizada. Antes da ensilagem em cada tempo, foram determinadas as populações de leveduras presentes na cana-de-açúcar. Decorridos 56 dias após a ensilagem, os silos experimentais foram abertos. O delineamento experimental utilizado foi o inteiramente casualizado em esquema fatorial, considerando os fatores aditivos e tempo pós-queima. Houve recontaminação da cana-de-açúcar pelas leveduras, elevando a população de 5,04 para 6,48 log ufc/g de forragem. Os teores de matéria seca (MS) após a abertura do silo reduziram em média 7,6 unidades percentuais em comparação aos observados na ensilagem. As silagens controle e com Lactobacillus buchneri tiveram menores recuperações da matéria seca (613 e $631 \mathrm{~g} / \mathrm{kg}$, respectivamente), em comparação às observadas nas silagens com cal e com a combinação Lactobacillus buchneri + cal (807 g/kg e 832 g/kg, respectivamente), fato que pode ser justificado pelo controle de levedura pela cal. Após a queima, as maiores variações foram na produção de gás e na recuperação de matéria seca: a produção de gás foi maior nos primeiros dias e diminuiu com o tempo após a queima, consequentemente, a recuperação de MS foi menor nos primeiros dias e aumentou com o tempo após a queima. O tempo após a queima altera o valor nutritivo da cana-de-açúcar fresca e das suas silagens, assim como a magnitude das perdas no processo de ensilagem.

Palavras-chave: cal micropulverizada, ensilagem, inoculante bacteriano, Lactobacillus buchneri 


\section{Introduction}

Pasture production decreases at a certain time of the year, so that forage resources have to be used such as hay and silage to feed ruminants. In this sense, the use of sugarcane as supplementary roughages has increased, because this crop is less demanding in terms of climatic conditions, soil fertility and topographical relief compared to crops such as corn and sorghum. Another important factor is that its harvest period that coincides with the period of forage scarcity in the pasture. However, it is a crop with a high risk of burning from accidental fire, that can prevent the use of the sugarcane crop in a direct cut system, therefore the forage could to be ensiled. However, there is little information in the literature on the time that the forage can remain in the field post burning.

When conserving the forage nutritive value, only the production of lactic acid is not efficient, because yeasts can use it and the available soluble carbohydrates for ethanol production (Walker, 19898). Acetic acid, that is usually an undesirable product in conventional silages, can controls yeast action (Moon, 1983), that in the case of sugarcane ensilage, is desirable. This effect was reported by Siqueira et al. (2007), who observed reductions in dry matter losses in sugarcane silage inoculated with heterolactic microorganisms.

Bernardes et al. (2007) observed higher ethanol contents and yeast populations in silages produced with burned sugarcane. These authors attributed this fact to the presence of sugars on the external surface of the cell wall resulting from the burning that increased yeast contamination.

For better control of yeasts, that are mainly responsible for dry matter losses during fermentation and ethanol production, appropriate chemical additives or bacterial inoculants specific to the crop should be used (Siqueira et al., 2007).

The objective of this study was to evaluation the effect of time post burning on sugarcane nutritive value before and after ensilage, losses during fermentation and to determine the effect of the additives calcium oxide micro pulverized and Lactobacillus buchneri and their association on the ensilage.

\section{Material and Methods}

The experiment was carried out at the Alta Mogiana Regional Pole for Agribusiness Technological Development and the College of Agrarian and Veterinary Sciences Unesp, Campus de Jaboticabal.
The IAC 86-2480 sugarcane cultivar was used, with 15 months of growth (the first cut) at the time of cutting. The sugarcane plantation was burnt at the end of the afternoon, on the day prior to the first cut. The stems were not separated from their link to the root until they reached the time predetermined for harvest, giving a condition of accidental fire.

On days 1, 4, 710 and 14 post burning, the forage was collected mechanically by a Menta Mit ensilager, ColhiFex model. After harvest, the chopped sugarcane was treated with the additives.

Five post burning times were adopted as treatments (1, 4, 7 and 10 and 14 days) in a factorial design with the additives (calcium oxide micro pulverized, Lactobacillus buchneri and calcium oxide micro pulverized + Lactobacillus buchneri) and the control group, totaling twenty treatments with three replications per treatment.

The calcium oxide micro pulverized was used at the dose of $1 \%$ in the sugarcane natural material, based on a study by Balieiro Neto et al. (2007), and the dose of the L. buchneri inoculant (Cepa NCIMB 40788) was $5 \times 10^{4} \mathrm{ufc} / \mathrm{g}$ silage natural material.

The experimental silos were $7 \mathrm{~L}$ plastic buckets closed with a plastic lid and sealed with adhesive tape. Bunsen valves were fitted in the lids for gas escape and $1.5 \mathrm{~kg}$ dry sand were placed at the bottom of the silo, separated from the silage forage by nylon cloth.

One sample of the forage per silo was removed before ensilage and of the silage when the silos were opened, for chemical and bromatological analyses. This sample was divided into two separate samples, one of which was prepared following the methodology described by Kung Jr. et al. (1984) to determine the $\mathrm{pH}$ using a potentiometer, and the other was weighed and taken to a forced air chamber at $55^{\circ} \mathrm{C}$ for 72 hours. After this period, these sub samples were again weighed, ground in a knife grinder until particles were less than $1 \mathrm{~mm}$ and stored in plastic pots.

Before ensilage, a second sample was removed of the forage to determine the epiphyte yeast count, following the method reported by Jobim et al. (1999). The quantities of dry matter (DM), crude protein (CP) were determined following methods described by Silva \& Queiroz (2002), and the neutral detergent fiber (NDF) and acid detergent fiber (ADF) by the sequential method, following techniques described by Robertson \& Van Soest (1981). To determine the cellulose, $72 \%$ sulfuric acid was used (Van Soest, 1994), while the lignin contents were calculated by the difference between the ADF and the cellulose. The true in vitro digestibility of the dry matter (DIVMS) was assessed according to (Van Soest, 1994). 
The silos were weighed after construction and stored at room temperature for 56 days. After this period, the silos were again weighed before opening to quantify gas losses, effluent losses and determine the dry matter recovery, according to Siqueira et al. (2007).

A randomized complete design was used in a $4 \times 5$ factorial arrangement with three replications, considering the factors additives (control, Lactobacillus buchneri, micropulverized calcium oxide micro pulverized, Lactobacillus buchneri + micropulverized calcium oxide micro pulverized,) and post-burning time (1, 4, 710 and 14 days), with three replications per treatment, totaling 60 experimental units. The data were analyzed by the PROC GLM of the SAS ${ }^{\circledR}$ program (SAS 1988) and the means were compared using the least squares method (LSMEANS) adopting a 5\% level of significance.

\section{Results and Discussion}

In the assessment of the post-burning time, the DM contents (Table 1) differed only on the seventh day of exposure (304 g/kg) possibly because of the rain $(14 \mathrm{~mm})$ in the night prior to the fourth day post-burning. A reduction in the DM content was expected in the sugarcane on the fourth day of assessment. However, this cut was made before the time necessary for the sugarcane to absorb the water and forage handling so that the excess water was eliminated from the forage surface. Consequently, the reduction in the DM content was observed only on the seventh day.

The DM content in the fresh forage was different among the additives, but this difference could be considered small, 0.9 percentage points, between the smallest and greatest DM content. The DM contents in the fresh sugarcane were greater than those observed by Bernardes et al. (2007), of $276 \mathrm{~g} / \mathrm{kg}$ DM in burnt sugarcane, and lower than that reported by Siqueira et al (2009), of 341g/kg DM in burnt sugarcane.

At opening, the DM contents of the control silos and the silos with Lactobacillus buchneri treated forage performed similarly, presenting the lowest DM contents during the period compared to the silages treated with calcium oxide micro pulverized and calcium oxide micro pulverized + Lactobacillus buchneri. The DM contents of the control and Lactobacillus buchneri silages at opening were close to the value of $201 \mathrm{~g} / \mathrm{kg}$ DM observed by Bernardes et al. (2007) in burnt sugarcane silages. Higher values were detected by Siqueira et al. (2009), who reported DM contents in burnt sugarcane silage and silage treated with Lactobacillus buchneri of $334 \mathrm{~g} / \mathrm{kg}$ DM or with $\mathrm{NaOH}(1 \%)$, of $327 \mathrm{~g} / \mathrm{kg}$ DM.
In the silages produced on the seventh day post burning, the DM contents at the assessment made at opening were the lowest and significantly similar to those of the first day, because when the sugarcane was ensilaged, they already presented a lower DM content.

The yeast population increased in response to time post burning (Figure 1), indicating that the potential for recontamination of the sugarcane plantation prevails for a long period.

The increase in the yeast population post burning resulted in great alcohol production in the silage. Thus, Bernardes et al. (2007) observed that silage where the sugarcane had been burnt presented higher ethanol contents (79 g/kg de DM) compared to in nature sugarcane (69 $\mathrm{g} / \mathrm{kg}$ de DM). The authors reported that the high temperatures during burning may have destroyed the wax layer that covers the cell wall of this plant species, a fact the causes the stems to crack and the exudation of cell content (sugars), increasing the microbial contamination and with this, there is greater alcohol fermentation in burnt sugarcane silages.

The control forage and the forage treated with Lactobacillus buchneri performed similarly for $\mathrm{pH}$ value at ensilage (Table 2), but the $\mathrm{pH}$ decreased over time post burning. The $\mathrm{pH}$ values in the forage of the first day, of the control forage and the forage treated with Lactobacillus buchneri were close to that observed by Siqueira et al. (2010), of 5.7 in the control forage and 5.6 in that treated with Lactobacillus buchneri.

Until the tenth day post burning, the $\mathrm{pH}$ values differed statistically among the forage treated with calcium oxide micro pulverized associated or not to Lactobacillus buchneri, but tended to decrease with the days post burning. The $\mathrm{pH}$ values found were high, that was expected, because calcium oxide micro pulverized is an alkaline product responsible for raising $\mathrm{pH}$. Siqueira et al. (2010) reported $11.7 \mathrm{pH}$ in sugarcane treated with $1 \% \mathrm{NaOH}$.

On the $14^{\text {th }}$ day there was significant difference among the forages treated with calcium oxide micro pulverized and with calcium oxide micro pulverized and Lactobacillus buchneri, but these forages continued with the highest $\mathrm{pH}$ values compared to the others.

At silo opening, regardless of the time post burning, all the silages treated with calcium oxide micro pulverized or calcium oxide micro pulverized and Lactobacillus buchneri had $\mathrm{pH}$ greater than the control silage or those treated with Lactobacillus buchneri, because, when calcium oxide micro pulverized was added at the time of ensilaging the sugarcane, the $\mathrm{pH}$ values increased. A similar fact occurred in the study by Siqueira et al. (2010), 
Table 1 - Chemical composition of fresh sugarcane and silage at different days after burning and treated with additives

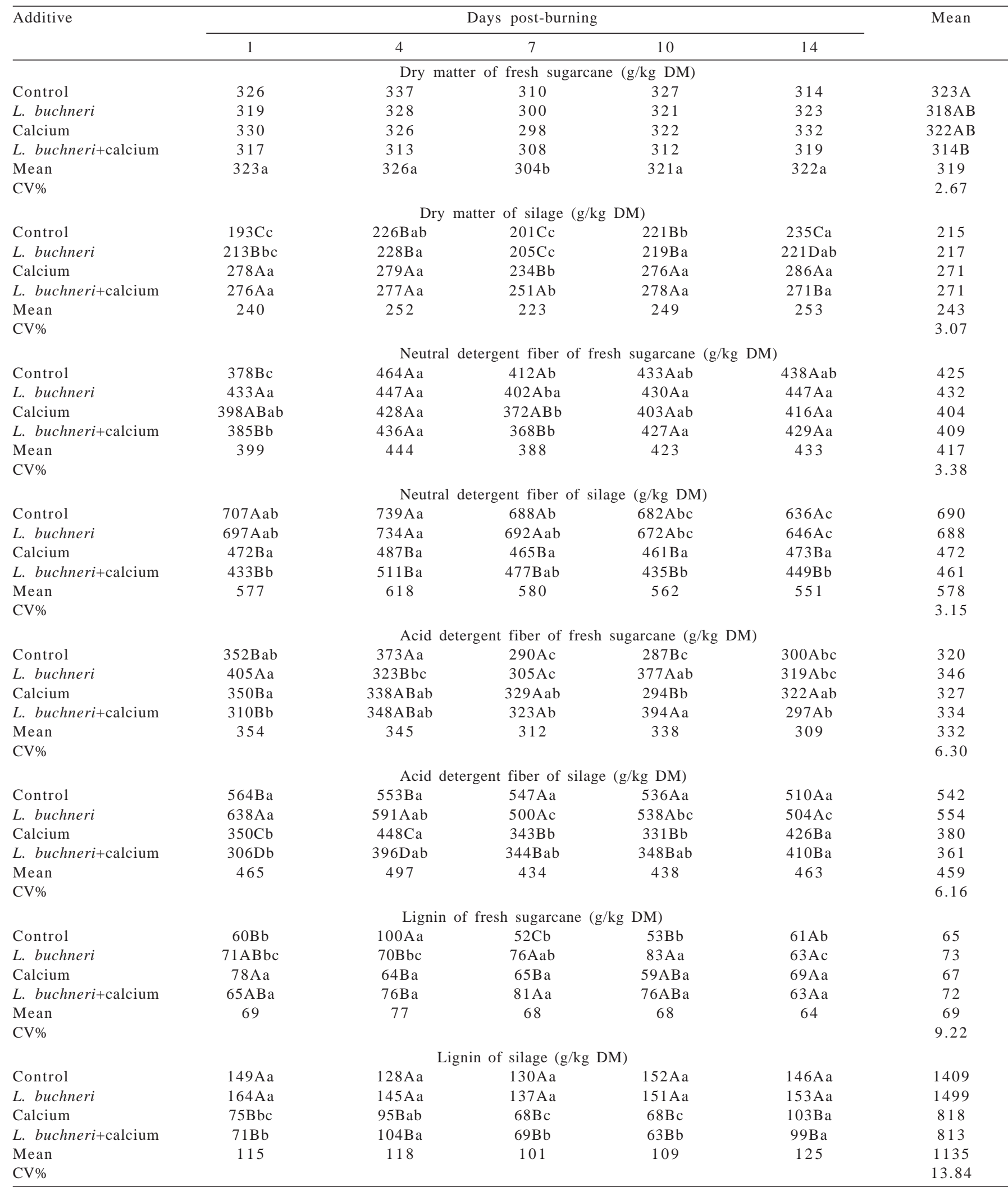

Means followed by the same uppercase and lowercase in the column on the line do not differ (P>0.05) by LSMEANS.

Calcium: calcium oxide micro pulverized; $\mathrm{CV} \%$ = coefficient of variation. 
who observed $\mathrm{pH}$ of 11.7 in silage treated with $\mathrm{NaOH}(1 \%)$ at ensilage and 4.86 at silo opening. The values obtained post burning differed from those determined at opening, but the difference was small.

Gas losses (Table 3) were high in the silos without additives (control) because there was probably a high yeast population and these microorganisms produced ethanol and carbon dioxide during fermentation, producing gas and consequently DM losses. Gas production in the control silage was very high compared to that observed by Pedroso et al. (2007), of 103 g/kg DM in nature sugarcane silage.

L. buchneri application did not decrease gas production in the silages produced on days $1,4,7$, and 10 post burning compared to the control (Table 3). As $L$. buchneri is a heterolactic bacteria, it can control the yeast population by producing acetic acid (Moon, 1983), thus it was expected that it would control yeast DM consumption

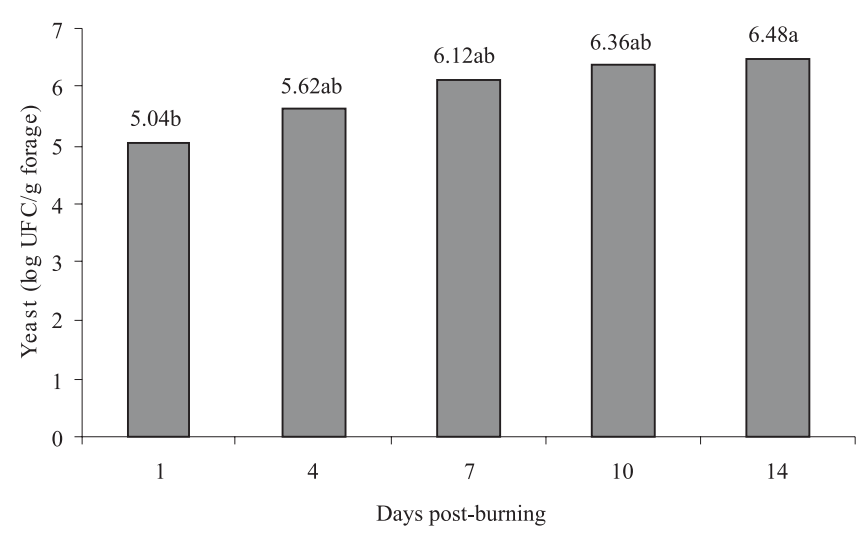

Figure 1 - Means of scores of epiphytic yeasts of sugarcane five times after burning. by giving a lower gas production, but this did not occur. Compared to the gas production observed by Siqueira et al. (2010), that was $112 \mathrm{~g} / \mathrm{kg}$ DM in burnt sugarcane silage treated with Lactobacillus buchneri, the result observed in the present study was better (236 g/kg DM gas loss). Explanations for this fact may include the differences in the action of this microorganism in the sugarcane cultivars and the quantity of sugars in the plant.

The silages treated with calcium oxide micro pulverized presented the lowest gas production (Table 3), probably because of the alkaline action of the calcium oxide micro pulverized, that controls the yeast. There was greater gas production on the first day of ensilage post burning (Table 3), but this production decreased over time. This reduction over the days may have been caused by the alteration in the sugar fractions of the sugarcane before ensilage. One of the parameters that indicated alteration was decrease in $\mathrm{pH}$ because of the prolonged post-burning time (Table 2). Allied to a possible change in the sugar profile, the influence of the initial $\mathrm{pH}$ itself on the microbial development is emphasized. Consequently the silage that presented possible changes in sugar profile might reduce or alter the action of the microorganisms.

According to the data (Table 3), the effluent production was the highest on the seventh day in all the silages, because on this day the forage presented the lowest DM content in the silage (Table 1). On the other days, effluent production and DM content were similar (Table 1 and 3). The silages without additives and with Lactobacillus buchneri produced the most effluent, while those treated with calcium oxide micro pulverized and Lactobacillus buchneri + calcium oxide micro pulverized had the lowest production.

Table 2 - pH values of fresh sugarcane and silage at different days after burning and treated with additives

\begin{tabular}{|c|c|c|c|c|c|c|}
\hline \multirow[t]{2}{*}{ Additive } & \multicolumn{5}{|c|}{ Days post-burning } & \multirow[t]{2}{*}{ Mean } \\
\hline & 1 & 4 & 7 & 10 & 14 & \\
\hline \multicolumn{7}{|c|}{ Fresh sugarcane } \\
\hline Control & $5.5 \mathrm{Ba}$ & $5.0 \mathrm{Bb}$ & $4.8 \mathrm{Bc}$ & 4.5Bd & $4.3 \mathrm{Ce}$ & 4.8 \\
\hline L. buchneri & $5.6 \mathrm{Ba}$ & 4.9Bb & $4.8 \mathrm{Bb}$ & 4.4Bc & $4.5 \mathrm{Cc}$ & 4.8 \\
\hline Calcium & $12.1 \mathrm{Aa}$ & 10.7Aab & $10.8 \mathrm{Aab}$ & $10.8 \mathrm{Aab}$ & $10.3 \mathrm{Ab}$ & 10.9 \\
\hline L. buchneri+calcium & 11.7Aa & $11.1 \mathrm{Ab}$ & $10.5 \mathrm{Ab}$ & $10.9 \mathrm{Ab}$ & $9.7 \mathrm{Bc}$ & 10.7 \\
\hline Mean & 8.7 & 7.9 & 7.7 & 7.7 & 7.2 & 7.8 \\
\hline \multirow[t]{2}{*}{ CV\% } & & & & & & 3.17 \\
\hline & & & Silage & & & \\
\hline Control & 3.7Bab & $3.6 \mathrm{Bbc}$ & $3.4 \mathrm{Bd}$ & 3.5Bcd & $3.8 \mathrm{Ba}$ & 3.6 \\
\hline L. buchneri & 3.6Ba & $3.5 \mathrm{Ba}$ & $3.4 \mathrm{Bb}$ & $3.6 \mathrm{Ba}$ & 3.5Cab & 3.5 \\
\hline Calcium & $4.2 \mathrm{Aa}$ & $3.9 \mathrm{Ab}$ & $4.2 \mathrm{Aa}$ & $4.2 \mathrm{Aa}$ & $4.1 \mathrm{Aa}$ & 4.1 \\
\hline L. buchneri+calcium & $4.1 \mathrm{Aa}$ & $3.9 \mathrm{Ab}$ & $4.2 \mathrm{Aa}$ & $4.2 \mathrm{Aa}$ & $4.1 \mathrm{Aa}$ & 4.1 \\
\hline Mean & 3.9 & 3.7 & 3.8 & 3.9 & 3.9 & 3.8 \\
\hline CV\% & & & & & & 2.00 \\
\hline
\end{tabular}

Means followed by the same uppercase and lowercase in the column on the line do not differ $(\mathrm{P}>0.05)$ by LSMEANS.

Calcium: calcium oxide micro pulverized; CV\% = coefficient of variation. 
Table 3 - Values of gas losses, effluent losses and dry matter recovery of sugarcane silage at different days after burning and treated with additives

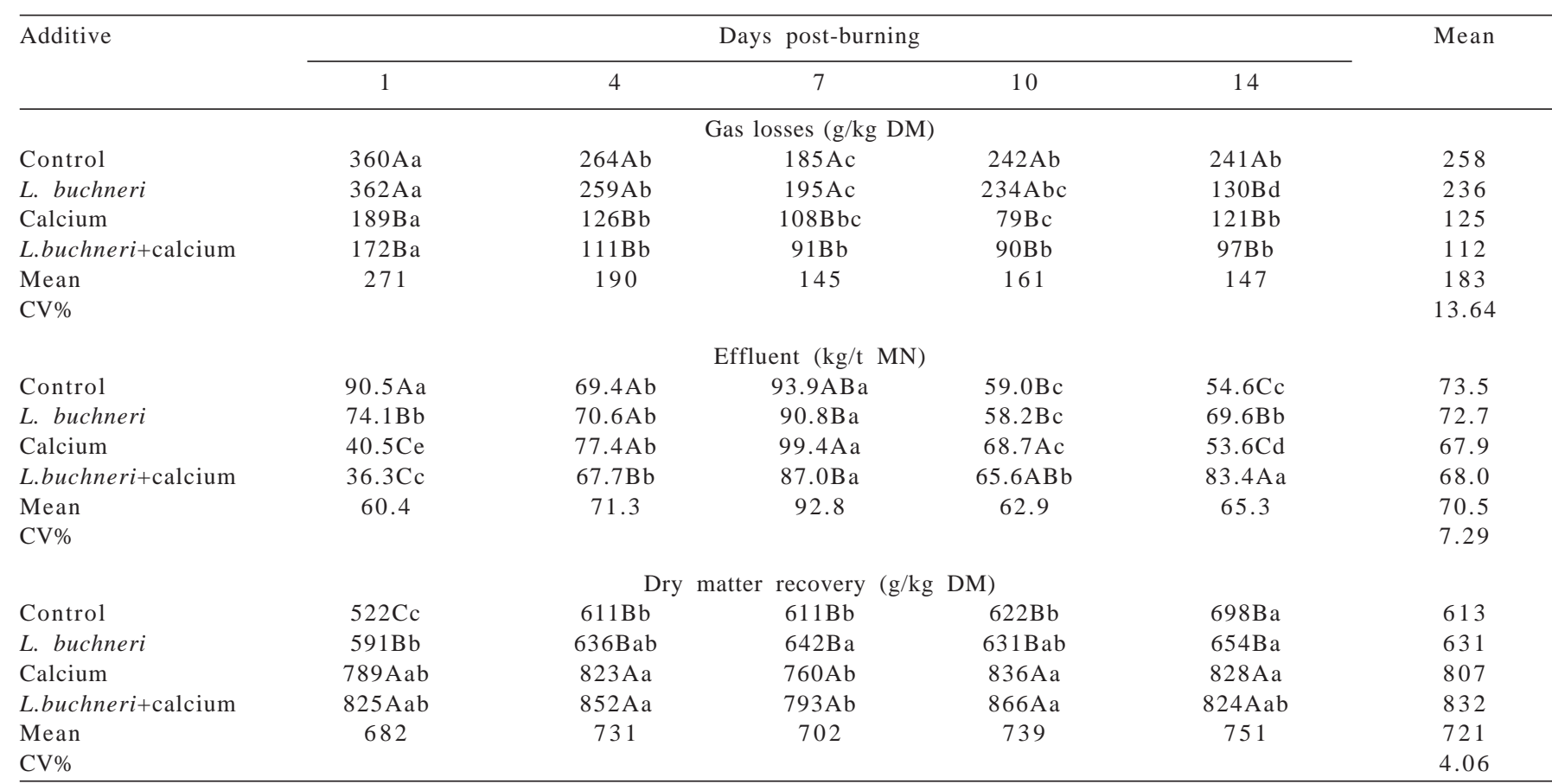

Means followed by the same uppercase and lowercase in the column on the line do not differ (P>0.05) by LSMEANS.

Calcium: Calcium oxide micro pulverized; $\mathrm{CV} \%=$ coefficient of variation.

Generally, the control silages and those with Lactobacillus buchneri had smaller DM recovery (Table 3), that can be justified by the greater gas production that resulted in DM loss and, as already reported, the yeast consumed DM for ethanol and carbon dioxide production. It was expected that Lactobacillus buchneri would help in yeast control, but this did not occur.

When calcium oxide micro pulverized was added, DM recovery increased because the yeast was controlled by the additives and the reduced in gas production. The assessments of the silage produced on the first day post burning indicated a small DM recovery, probably because this day presented the greatest gas production, one of the main forms of DM loss. On the seventh day there was also little DM recovery, explained by the high effluent production, that could have up to $37 \mathrm{~g} / \mathrm{kg}$ DM (Bernardes et al., 2003), also a form of dry matter loss. On the other assessment days, DM recovery was higher and there was no statistical difference among the days.

The NDF contents (Table 1 ) were smaller in the forage treated with calcium oxide micro pulverized, possibly because the effect of alkaline hydrolysis on the fiber occurs quickly. Furthermore, during the drying in the forced air chamber, this reaction may still be happening, that justified the reduction in the NDF fraction. In a study by Pires et al. (2006), who assessed $\mathrm{NaOH}$ doses (0, 2.5, 5 and $7.5 \% \mathrm{DM}$ ) on sugarcane bagasse storage for 1, 3, 5 and 7 days, did not report effect of days on any cell wall constituent, but the doses had an effect on all these parameters, that proved the rapid action of the sodium hydroxide. The control silages and those treated with Lactobacillus buchneri presented the greatest NDF contents before ensilage.

The sugarcane without additives presented the lowest NDF content in fresh forage on the first day (Table 1), because over time loss may have occurred of the sugarcane cell content post burning the sugar cane plantation. The decrease in NDF on the seventh day, compared to the fourth day, may be justified by the possible transformation of the carbohydrates because of rain, that also altered the DM concentration (Table 1). In the silages treated with calcium oxide micro pulverized, the same performance was also observed reported in the control forage. There was statistical difference in the NDF contents before ensilage in all the forages except the forage treated with Lactobacillus buchneri.

NDF contents higher than those observed in the present experiment were reported by Siqueira et al. (2009), who observed $498 \mathrm{~g} / \mathrm{kg}$ DM NDF in fresh sugarcane. The NDF contents in the sugarcane treated with Lactobacillus buchneri in the present study (515 g/kg DM) were lower than that observed by Siqueira et al. (2009). 
At silo opening, the lowest NDF contents were observed in the silages treated with calcium oxide micro pulverized, because there was better preservation of the cell content, that is, calcium oxide micro pulverized was shown to be a good additive for microorganism control during fermentation. Alkaline hydrolysis of the cell wall may also have taken place, decreasing the NDF content in the silage, a reaction that has been observed previously at ensilage. The silages treated with Lactobacillus buchneri and the control presented high NDF content, that can be justified by the consumption of the cell content by uncontrolled microorganisms during fermentation. The NDF contents in the silage treated with calcium oxide micro pulverized were greater than those observed by Balieiro Neto et al. (2007) in nature sugarcane silage treated with calcium oxide micro pulverized at $1 \%$ and $2 \%$ (5853 g/kg DM and $495 \mathrm{~g} / \mathrm{kg} \mathrm{DM,}$ respectively).

The ADF contents (Table 1) observed in the control forage were lower than those reported by Bernardes et al. (2007) of 415 g/kg DM in burnt sugarcane silage. Regarding days post burning, the lowest contents were observed on the $7^{\text {th }}, 10^{\text {th }}$ and $14^{\text {th }}$ days and the highest, on the first and fourth days. The ADF contents in the forages treated on the fourth, seventh and $14^{\text {th }}$ days were close to the ADF content observed by Siqueira et al. (2009) in burnt sugarcane silage treated with Lactobacillus buchneri, that was $316 \mathrm{~g} / \mathrm{kg}$ DM.

The ADF contents observed in the silages treated with calcium oxide micro pulverized were close to those reported by Balieiro Neto et al. (2007) that of $335 \mathrm{~g} / \mathrm{kg}$ DM ADF at the ensilage of in nature sugarcane treated with $1 \%$ calcium oxide micro pulverized. On the tenth day the ADF content in the forage was the lowest observed in the silage with calcium oxide micro pulverized, and on the first day the highest NDF content was observed with the use of this additive. When calcium oxide micro pulverized and Lactobacillus buchneri were used the highest ADF contents were observed in the fresh sugarcane on the tenth and fourth days.

At silo opening, the highest ADF contents were observed in the silage treated with Lactobacillus buchneri (Table 1), that were superior to those observed by Siqueira et al. (2009) in burnt sugarcane silage treated with this additive (477 g/kg DM). The ADF contents observed in the silage treated with calcium oxide micro pulverized + Lactobacillus buchneri were the lowest and were lower than those reported by Balieiro Neto et al. (2007) in in nature sugarcane silage treated with $1 \%$ calcium oxide micro pulverized, of $459 \mathrm{~g} / \mathrm{kg}$ DM.
Regarding time post burning, when the silage was treated with Lactobacillus buchneri, the ADF contents tended to decrease over time, while in the control silage this content did not differ statistically (Table 1).

The silages treated with calcium oxide micro pulverized associated or not to Lactobacillus buchneri performed similarly for days post burning so that, from the first to the fourth day, the ADF content increased and from the fourth to the tenth day it decreased and then increased again until the $14^{\text {th }}$ day (Table 1 ).

In the sugarcane without additives, the highest lignin content was observed on the fourth day post burning that was the same day on which the NDF and ADF contents were the highest. The lignin content observed by Siqueira et al. (2009) in the burnt sugarcane forage was $87 \mathrm{~g} / \mathrm{kg}$ DM and was higher than that observed in the fresh sugarcane without additives on the first, seventh, $10^{\text {th }}$ and $14^{\text {th }}$ days post burning.

The lignin contents observed during ensilage in the forages treated with Lactobacillus buchneri on the first, fourth and seventh days were close to those reported by Siqueira et al. (2009) of $72 \mathrm{~g} / \mathrm{kg}$ DM in burnt sugarcane silage treated with Lactobacillus buchneri.

Using calcium oxide micro pulverized as additive resulted in the lowest lignin contents in fresh sugarcane assessed on the fourth, seventh, $10^{\text {th }}$ and $14^{\text {th }}$ days post burning when calcium oxide micro pulverized alone was used and on the $1^{\text {st }}$ and $4^{\text {th }}$ days when calcium oxide micro pulverized was used in association with Lactobacillus buchneri. The contents observed were close to those reported by Balieiro Neto et al. (2007) of $62 \mathrm{~g} / \mathrm{kg}$ DM in sugarcane silage treated with calcium oxide micro pulverized at $1 \%$.

At silo opening, the lignin contents in the control silages and silages treated with Lactobacillus buchneri (Table 1) were higher than those observed by Siqueira et al. (2009) in untreated sugarcane silage and silage treated with Lactobacillus buchneri, of 99 g/kg DM and 80 g/kg DM, respectively. The highest lignin contents at silo opening in the silages treated with calcium oxide micro pulverized associated or not with Lactobacillus buchneri were observed on the $4^{\text {th }}$ and $14^{\text {th }}$ days. These contents were superior to those observed by Balieiro Neto et al. (2007) of $80 \mathrm{~g} / \mathrm{kg} \mathrm{DM}$ at opening of in nature sugarcane silage treated with calcium oxide micro pulverized at $1 \%$.

The CP contents in the fresh sugarcane (Table 4) were higher than those reported by Siqueira et al. (2009) at the ensilage of this burnt forage without additives (13 g/kg $\mathrm{DM})$ and treated with Lactobacillus buchneri (14 g/kg 
DM) and close to those reported by Balieiro Neto et al. (2007) for in nature sugarcane silages without additives $(30 \mathrm{~g} / \mathrm{kg}$ DM) and treated with $1 \%$ calcium oxide micro pulverized (27 g/kg DM).

The CP contents decreased from the first to the fourth day post burning, but they increased from this day to the $14^{\text {th }}$ day, regardless of the additives used. At silo opening, the highest CP contents were observed in the control silage and the silage treated with Lactobacillus buchneri. Siqueira et al. (2009) observed lower CP contents in untreated burnt sugarcane silage ( $23 \mathrm{~g} / \mathrm{kg} \mathrm{DM}$ ) and sugarcane silage treated with Lactobacillus buchneri (21 g/kg DM). The CP contents were close to those observed by Bernardes et al. (2007) of $32 \mathrm{~g} / \mathrm{kg}$ DM in burnt sugarcane silage.

The CP contents were lowest when the silages treated with calcium oxide micro pulverized associated or not with
Lactobacillus buchneri were opened. Balieiro Neto et al. (2007) observed greater CP contents (31 g/kg DM) in the in nature sugarcane silage treated with calcium oxide micro pulverized at $1 \%$.

The lowest CP contents were on the fourth day post burning, the same day when the lowest $\mathrm{CP}$ contents were observed at ensilage. The highest $\mathrm{CP}$ content was observed on the $14^{\text {th }}$ day, when the highest CP content was observed at ensilage. Differences were not observed in the digestibility values at ensilage (Table 5).

The sugarcane presented lower digestibility only on the fourth day post burning, probably because of the higher NDF and lignin contents compared to the other days, and these fractions are related negatively to forage digestibility.

At opening, the control silages and silages treated with Lactobacillus buchneri presented the lowest digestibility

Table 4 - Crude protein of fresh sugarcane and silage at different days after burning and treated with additives

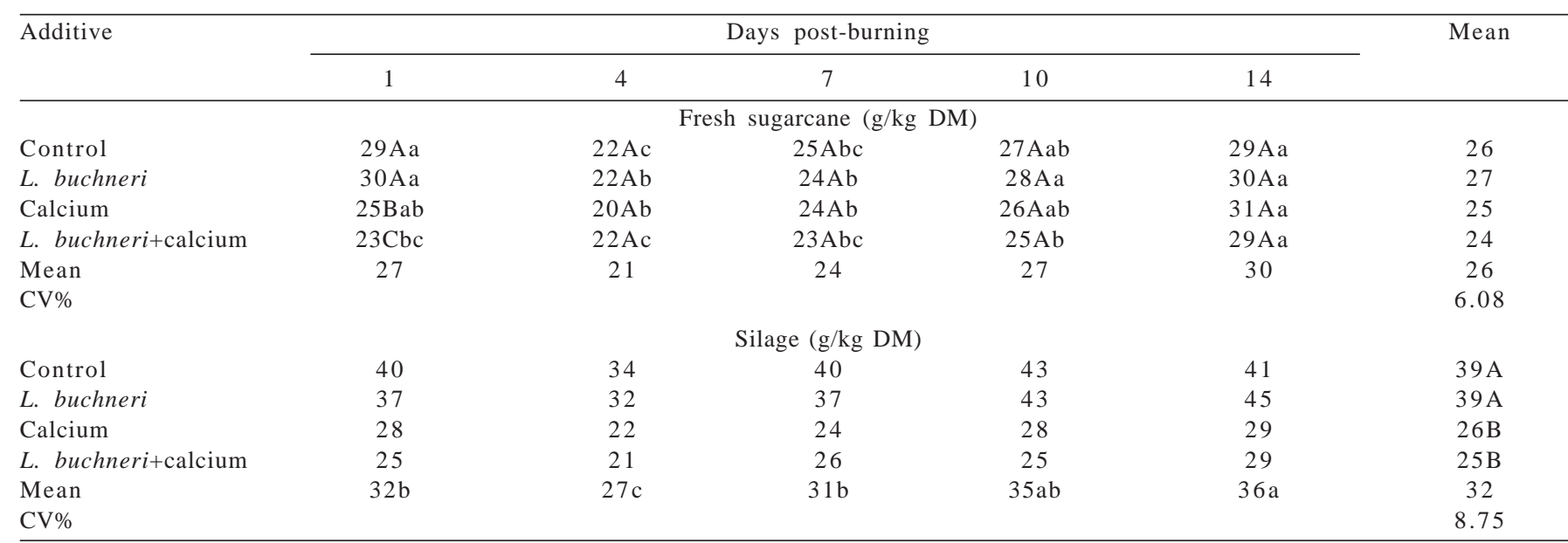

Means followed by the same uppercase and lowercase in the column on the line do not differ (P>0.05) by LSMEANS.

Calcium: Calcium oxide micro pulverized; $\mathrm{CV} \%$ = coefficient of variation.

Table 5 - True in vitro digestibility of the dry matter of fresh sugarcane and silage at different days after burning and treated with additives

\begin{tabular}{|c|c|c|c|c|c|c|}
\hline \multirow[t]{2}{*}{ Additive } & \multicolumn{5}{|c|}{ Days post-burning } & \multirow[t]{2}{*}{ Mean } \\
\hline & 1 & 4 & 7 & 10 & 14 & \\
\hline \multicolumn{7}{|c|}{ Fresh sugarcane (g/kg DM) } \\
\hline Control & 666 & 603 & 626 & 612 & 675 & $637 \mathrm{~A}$ \\
\hline L. buchneri & 637 & 595 & 647 & 610 & 660 & $630 \mathrm{~A}$ \\
\hline Calcium & 657 & 564 & 625 & 637 & 680 & $632 \mathrm{~A}$ \\
\hline L. buchneri+calcium & 639 & 585 & 636 & 690 & 658 & $642 \mathrm{~A}$ \\
\hline Mean & $650 \mathrm{a}$ & $587 \mathrm{~b}$ & $633 a$ & $637 \mathrm{a}$ & $668 \mathrm{a}$ & 635 \\
\hline CV\% & & & & & & 5.23 \\
\hline \multicolumn{7}{|c|}{ Silage (g/kg DM) } \\
\hline Control & 424Bab & 393Bb & 403Bb & $480 \mathrm{Ba}$ & 483Ва & 437 \\
\hline L. buchneri & 455Bab & $401 \mathrm{Bb}$ & 417Bab & 469Ba & 461Bab & 441 \\
\hline Calcium & $630 \mathrm{Ab}$ & 553Ac & $681 \mathrm{Aa}$ & $604 \mathrm{Abc}$ & $551 \mathrm{Ac}$ & 604 \\
\hline L. buchneri+calcium & $658 \mathrm{Aa}$ & $537 \mathrm{Ab}$ & $619 \mathrm{Aa}$ & 643Aa & 609Aa & 613 \\
\hline Mean & 542 & 471 & 530 & 549 & 526 & 524 \\
\hline CV\% & & & & & & 7.10 \\
\hline
\end{tabular}

Means followed by the same uppercase and lowercase in the column on the line do not differ (P>0.05) by LSMEANS.

Calcium: Calcium oxide micro pulverized; $\mathrm{CV} \%=$ coefficient of variation. 
values compared to those treated with calcium oxide micro pulverized. Balieiro et al. (2007) assessed in nature sugarcane silage with calcium oxide micro pulverized and reported that soluble carbohydrate consumption by microorganisms resulted in a proportional rise in the fiber fraction, reducing the nutritive value of the silage and further observed that the silages with the highest digestibility values were those that had the highest nonfibrous carbohydrate contents and the lowest NDF contents.

The highest digestibility values were observed in the silage treated with calcium oxide micro pulverized that also presented the lowest DM losses and the lowest NDF contents. At opening, the performance was the same as at ensilage, so that the digestibility on the fourth day was the lowest and the NDF contents, the highest.

\section{Conclusions}

The time post burning alters the nutritive value of the fresh sugarcane and its silage, and the size of the losses from the ensilage process, but the maximum time for the sugarcane harvest could not be determined.

\section{References}

BALIEIRO NETO, G.; SIQUEIRA, G.R.; REIS, R.A. et al. Óxido de cálcio como aditivo na ensilagem de cana-de-açúcar. Revista Brasileira de Zootecnia, v.36, n.5, p.1231-1239, 2007.

BERNARDES, T.F.; REIS, R.A.; SIQUEIRA, G.R. et al. Avaliação da queima e da adição de milho desintegrado com palha e sabugo na ensilagem de cana-de-açúcar. Revista Brasileira de Zootecnia, v.36, n.2, p.269-275, 2007.

BERNADES, T.F.; REIS, R.A.; AMARAL, R.C. et al. Produção e composição do efluente das silagens de capim-Marandu
(Brachiaria brizantha cv. Marandu) submetidas à adição de polpa cítrica peletizada. In: REUNIÃO ANUAL DA SOCIEDADE BRASILEIRA DE ZOOTECNIA, 40., 2003, Santa Maria. Anais... Santa Maria: Sociedade Brasileira de Zootecnia, 2003. (CD-ROM).

JOBIM, C.C.; REIS, R.A.; SCHOCKEN-ITURRINO, R.P. et al. Desenvolvimento de microrganismos durante a utilização de silagens de grãos úmidos de milho e de espigas de milho sem brácteas. Acta Scientiarum, v.21, p.671-676, 1999.

KUNG JR., L.; GRIEVE, D.B.; THOMAS, J.W. Added ammonia or microbial inoculant for fermentation and nitrogenous compounds of alfalfa ensiled at various percents of dry matter. Journal of Dairy Science, v.67, p.299-306, 1984

MOON, N.J. Inhibition of the growth of acid tolerant yeasts by acetate, lactate and propionate and their synergistic mixtures. Journal of Applied Bacteriology, v.55, p.453-460, 1983.

PEDROSO, A.F.; NUSSIO, L.G.; LOURES, D.R.S. et al. Efeito do tratamento com aditivos químicos e inoculantes bacterianos nas perdas e na qualidade de silagens de cana-de-açúcar. Revista Brasileira de Zootecnia, v.36, n.3, p.558-564, 2007.

PIRES, A.J.V.; REIS, R.A.; CARVALHO, G.G.P. et al. Bagaço de cana-de-açúcar tratado com hidróxido de sódio. Revista Brasileira de Zootecnia, v.35, n.3, p.953-957, 2006.

ROBERTSON, J.B.; VAN SOEST, P.J. The detergent system of analysis and its application to human foods. In: JAMES, W.P. T.; THEANDER, O. (Eds.) The analysis of dietary fiber in food. New York: Marcel Dekker, 1981. p.123-158.

SILVA, D.J.; QUEIROZ, A.C. Análise de alimentos: métodos químicos e biológicos. 3.ed. Viçosa, MG: UFV, 2002. 235p.

SIQUEIRA, G.R.; REIS, R.A.; SCHOCKEN-ITURRINO, R.P. et al. Influência da queima e aditivos químicos e bacterianos na composição química de silagens de cana-de-açúcar. Archivos de Zootecnia, v.58, p.43-54, 2009.

SIQUEIRA, G.R.; REIS, R.A.; SCHOCKEN-ITURRINO, R.P. et al. Queima e aditivos químicos e bacterianos na ensilagem da cana-de-açúcar. Revista Brasileira de Zootecnia, v.39, n.1, p.103-112, 2010.

SIQUEIRA, G.R.; REIS, R.A.; SCHOCKEN-ITURRINO, R.P. et al. Associação entre aditivos químicos e bacterianos na ensilagem de cana-de-açúcar. Revista Brasileira de Zootecnia, v.36, n.4, p.789-798, 2007.

VAN SOEST, P. Nutritional ecology of the ruminant. 2.ed. Ithaca: Cornell University Press, 1994. 476p.

WALKER, G.M. Yeast physiology and biotechnology. London: Wiley Editorial Offices, 1998, 350p. 